\title{
Experiments in Financial Liberalization: The Mexican Banking Sector
}

\author{
Rubén Hernández-Murillo
}

\begin{abstract}
Since the liberalization of its trade in the mid-1980s, Mexico has pursued an aggressive globalization strategy, which today makes it the country with the most free trade agreements in the world. This liberalization strategy has also included the banking sector, particularly since 1997, when all restrictions to the entry of foreign banks were removed. The history of the banking sector in Mexico includes episodes of nationalization in 1982, privatization in 1992, and near-complete failure in 1995. Since then, however, the Mexican government has undertaken a series of bold reforms that have contributed to the modernization of its financial system. This paper documents the evolution of Mexico's banking sector starting from its nationalization in 1982 and culminating with the increased entry of foreign banks in recent years that has driven the recovery of bank credit to the private sector. (JEL G18, G21, G28, P11, D23)
\end{abstract}

Federal Reserve Bank of St. Louis Review, September/October 2007, 89(5), pp. 415-32.

$\mathrm{n}$ the mid-1980s Mexico started to liberalize its trade; and, since the signing of the North American Free Trade Agreement (NAFTA) in early 1994, Mexico has followed an aggressive globalization strategy, placing about 90 percent of its trade flows under free trade agreements with over 40 countries. These polices have made Mexico the country with the most free trade agreements in the world. ${ }^{1}$ Mexico's liberalization strategy has also included its financial sector and, in particular, the banking industry.

Mexico's experience with financial liberalization provides an interesting case study for at least two reasons. First, economic theory suggests that financial liberalization bolsters economic growth. Mexico's path toward financial liberalization has been an arduous one and includes several failed attempts, which, until recently, prevented the

1 At the time of this writing, Mexico was negotiating a free trade agreement with Mercosur to join this bloc as an associate member. development of its banking sector and limited the growth of financial credit to the private sector, which is necessary for economic development.

Second, given the nature of some of the experiments that have been followed, Mexico's experience can also provide lessons about the effectiveness of aggressive openness reforms targeted at improving competition in the banking industry and at increasing credit to the private sector-namely, the elimination of all restrictions on foreign ownership of banking assets in 1997, which allowed foreign banks to dominate the sector. One of the most recent developments in this regard is the approval in 2006 of Wal-Mart's bid to create a commercial bank in Mexico.

In this paper I describe the evolution of Mexico's banking sector by reviewing (roughly in chronological order) the reforms that have been implemented since 1982, when Mexico's financial system was nationalized. Continuing problems with Mexico's institutional and legal framework persisted even after the banking sector

Rubén Hernández-Murillo is a senior economist at the Federal Reserve Bank of St. Louis. The author thanks Gabriel Cuadra at Banco de Mexico for help in obtaining the data used for the figures. Marcela Williams and Christopher Martinek provided research assistance.

(C) 2007, The Federal Reserve Bank of St. Louis. Articles may be reprinted, reproduced, published, distributed, displayed, and transmitted in their entirety if copyright notice, author name(s), and full citation are included. Abstracts, synopses, and other derivative works may be made only with prior written permission of the Federal Reserve Bank of St. Louis. 
Figure 1

\section{Credit by Commercial Banks}

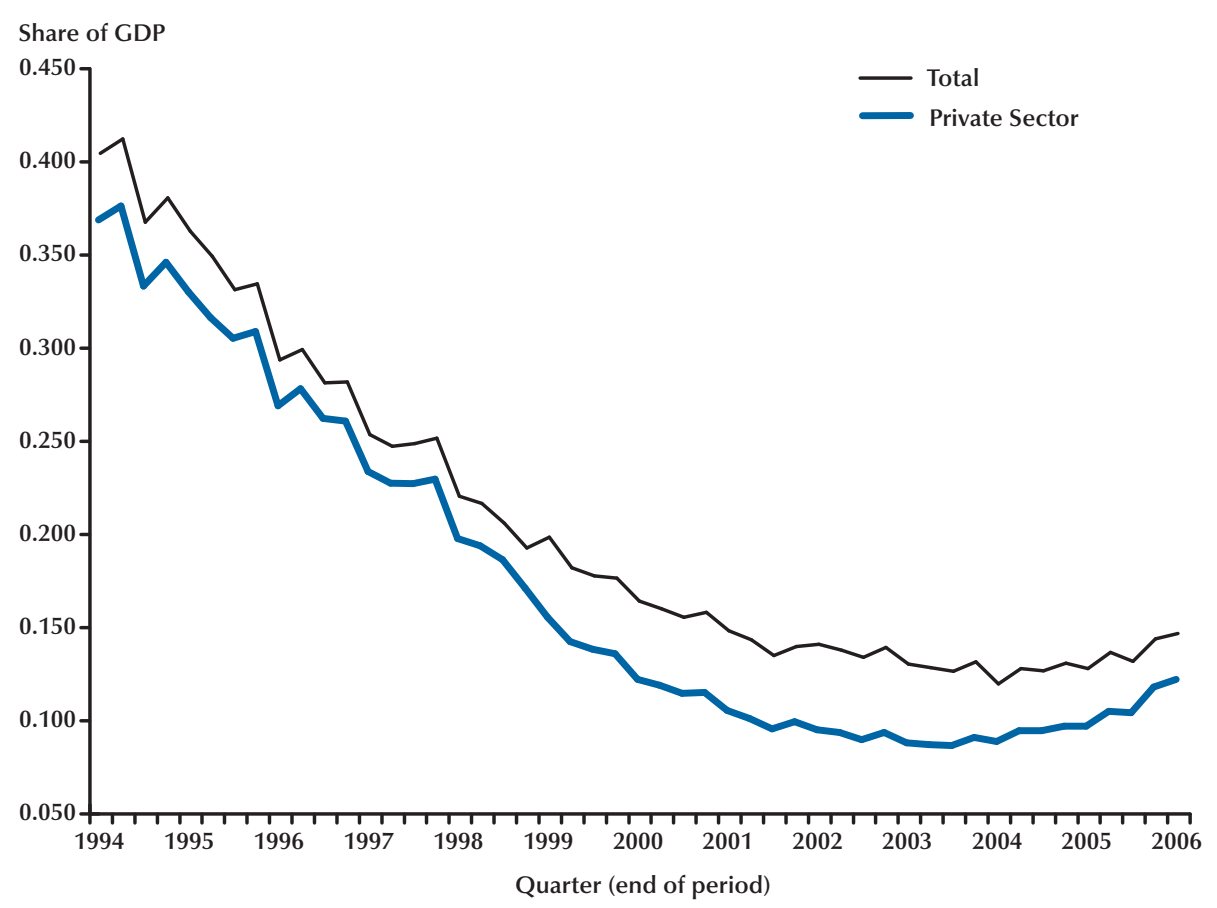

SOURCE: Banco de México.

was re-privatized in 1992 and generated distorted incentives among lenders who engaged in risky lending practices. These practices ultimately led to a banking crisis by 1995, forcing the Mexican government to implement a massive rescue program to prevent generalized failure in the sector.

Since 1997, however, the Mexican government has undertaken a series of bold reforms: for example, extensive reforms to banks' accounting standards, elimination of all barriers to the entry of foreign banks, reforms to personal and business bankruptcy laws, improvements in credit rating technology and regulatory changes to promote the use of credit bureaus, reforms to capitalization and risk management standards that conform with the recommendations of the Basel II accords, and, more recently, reforms that promote the securitization of mortgage loans. By the end of 2006, banks in Mexico were owned almost entirely by foreign financial institutions, with subsidiaries of foreign banks representing more than 80 percent of total banking assets in the system.

These reforms have started to produce positive results and promise even more favorable changes in the years ahead. The most positive result thus far is that the credit crunch that followed the banking crisis of 1995 appears to have subsided; and bank credit to the private sector has been growing rapidly since 2004. (See Figure 1.)

\section{NATIONALIZATION OF THE BANKING SYSTEM, 1982}

At the end of the administration of President López Portillo, in 1982, Mexico experienced its most severe crisis since 1932, with real gross domestic product (GDP) declining by 4.7 percent in the fourth quarter of 1982. (See Figure 2.) The crisis was triggered by adverse shocks to oil prices 


\section{Figure 2}

\section{Real GDP}

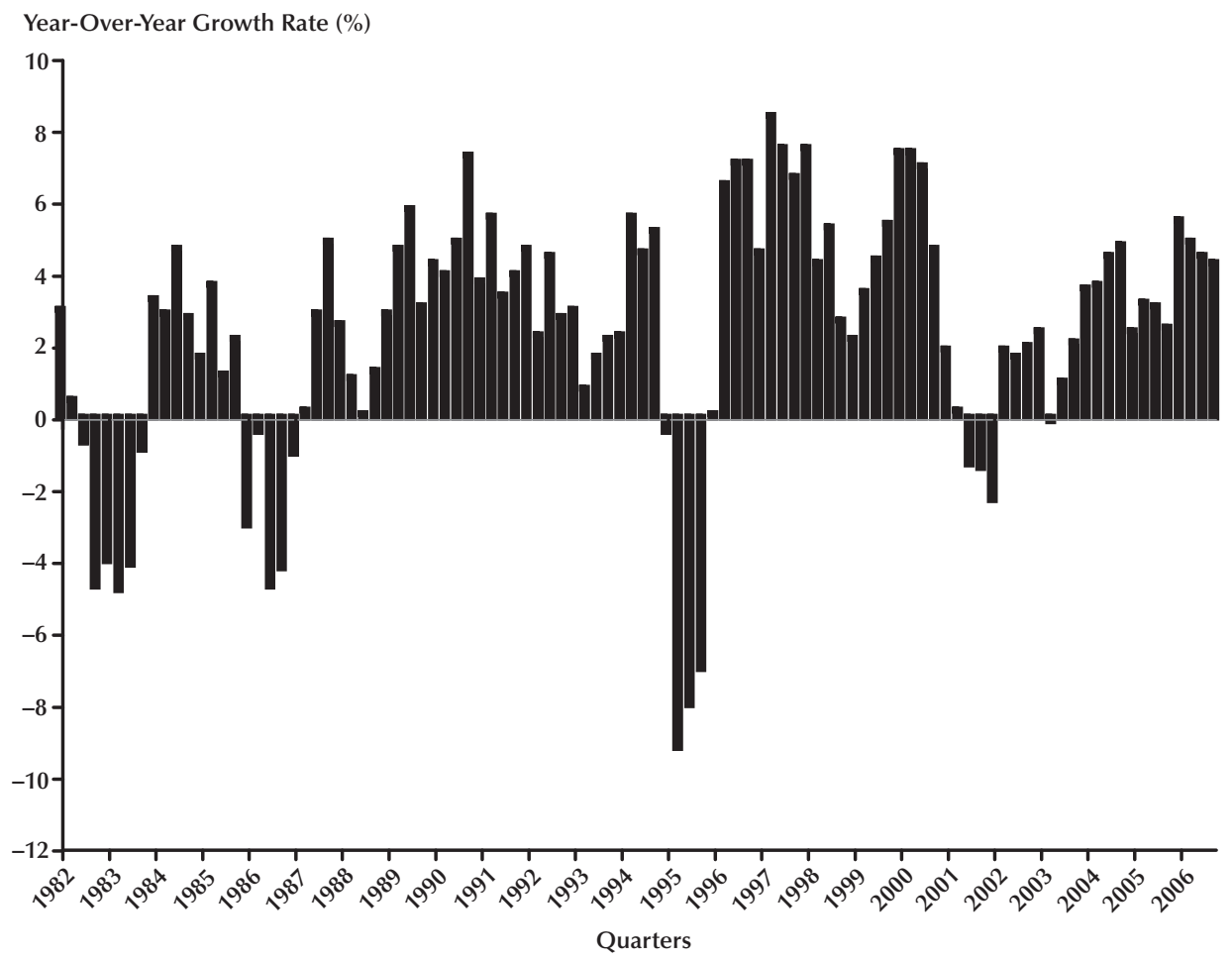

SOURCE: Banco de México.

and world interest rates, but was ultimately caused by a disorderly expansionary fiscal policy largely supported by borrowing from international capital markets and by borrowing from the central bank (i.e., simply printing money to finance the deficit), which the government had followed since the 1970s. The government devalued the currency and defaulted on foreign debt payments, which caused Mexico to lose access to international credit markets.

In September 1982, the government also announced a decree to amend the constitution and nationalize 58 of the 60 banks in the sector. The exceptions were Citibank, which has had a presence in Mexico since 1929, and Banco Obrero, which was owned by a labor union. ${ }^{2}$

During the new administration of President Miguel de la Madrid Hurtado, the banking system was consolidated into a smaller number of banks, but remained heavily regulated otherwise. The number of commercial banks was reduced to 29 in 1983, to 20 in 1985, and finally to 18 in 1988.

In the early 1980s, the banking sector was the dominant financial intermediary and, along with the stock market, it constituted the core of the financial system. However, its role was diminished throughout the nationalization episode as the government restricted universal banking activities, prohibiting banks from forming integrated financial groups to offer other financial services beyond banking; consequently, other types of financial intermediaries began to take on more important roles. ${ }^{3}$ Private investors turned to alternative sources of financing, such as commercial paper,

2 See Bubel and Skelton (2002).

3 With the re-privatization of the banking sector in 1992, banks would again operate under a universal banking structure. 
further reducing the role of banks as financial intermediaries.

From 1982 to 1984, for example, brokerage firms essentially controlled the sale and purchase of financial instruments, which included commercial paper and bonds. ${ }^{4}$ Although short-term Mexican Treasury bills had been introduced since 1978, the interest rate on these instruments was set exogenously. This policy limited the extent of their use to finance the public deficit. In 1982, however, a new auction mechanism was developed for their exchange, allowing the market to determine the rate of return. ${ }^{5}$

In 1984, the new administration began to sell off bank operations that did not take deposits and make loans. The goal was to separate different financial intermediation roles among independent types of operations to allow private investors (often former bank owners) to form and operate stock brokerage firms, insurance and re-insurance firms, and currency exchange firms. ${ }^{6}$

After being excluded from international credit markets, from 1982 to 1988, the Mexican government turned to domestic credit to finance its fiscal deficits, imposing heavy reserve requirements on the newly nationalized banks. As a result, bank lending to the private sector declined dramatically. ${ }^{7}$ The government also imposed many other constraints on the banking sector, which induced lending inefficiencies, including interest rate ceilings on bank deposits and loans, as well as mandated lending quotas on highpriority economic sectors. ${ }^{8}$

Commercial banks could freely allocate only up to 25 percent of their credit, for which they could charge market lending rates; but they were required to allocate all other loans to the federal government or to targeted sectors of the economy. Furthermore, until 1989, the government also controlled banks' operational procedures, such as deciding on the location and number of bank

\footnotetext{
4 See Trigueros (1995).

5 See Katz (1990).

6 See Gruben and McComb (1997).

7 See Gruben and McComb (1997).

8 See Gelos and Werner (2002).
}

branches that could be created and the number of employees that were hired and approving the banks' annual budgets for income and expenses.

\section{FINANCIAL LIBERALIZATION REFORMS, 1988-89}

Starting in 1988, a new series of reforms were initiated to make the financial system more competitive. Among these reforms was the elimination in April 1989 of controls on interest rates and the sectoral quotas imposed by the government on commercial lending. The reserve requirements on private deposits were eliminated in 1991. These reforms culminated with the re-privatization of the banking sector in 1991 and 1992 under the administration of President Carlos Salinas de Gortari.

By this time, the Mexican money market had become more liquid and the government increased the issuance of short-term Treasury bills so that it no longer relied on commercial bank financing. ${ }^{9}$ Mexico had also regained entry to international capital markets by 1989 after the implementation of the Brady Plan and enactment of a stabilization plan (begun in 1987). ${ }^{10}$ Bank credit to the private sector began to increase dramatically after $1989 .{ }^{11}$

Development banks, that is, state-controlled banks charged with providing credit to private and state-owned enterprises in targeted sectors in the economy, also changed significantly. The share of loans allocated to state-owned firms decreased and loans were increasingly allocated to private enterprises. At the same time, however, total development bank credit to nonfinancial firms in the private sector decreased as the regulations on commercial banking were removed. ${ }^{12}$

During this period, the regulatory framework of the financial system was updated and new laws

\footnotetext{
9 See Gruben and McComb (1997).

${ }^{10}$ The Brady Plan, named after U.S. Treasury Secretary Nicholas Brady, was the mechanism used to restructure bonds issued by many Latin American countries that defaulted on their debt in the 1980s. Mexico was the first country to repay its Brady debt, in 2003.

11 See Gelos and Werner (2002).

${ }^{12}$ See Gonzalez-Anaya and Marrufo (2001).
} 
were drafted to regulate commercial banks and insurance and bonding companies, as well as the stock market and investment banks. In 1990, the Salinas administration created a new deposit insurance authority, FOBAPROA (Banking Fund for the Protection of Savings).

In July 1990, the government passed laws allowing for the formation of integrated financial groups that could consolidate different types of financial intermediation under a scheme of universal banking. The law allowed for the integration of banks with leasing, factoring, currency exchange, mutual fund management, and asset-based warehousing firms; and, separately, it allowed for the integration of brokerage firms with leasing, factoring, currency exchange, mutual fund management, and asset-based warehousing firms. ${ }^{13}$ The final group allowed was holding companies. ${ }^{14}$ Initially, however, restrictions remained for the integration of commercial banks with brokerage firms and insurance and bonding firms. ${ }^{15}$

\section{THE PRIVATIZATION OF THE BANKING SECTOR, 1990-92}

The privatization of commercial banks was part of a broad program of privatization of staterun enterprises under a general stabilization program that included increased fiscal discipline and cuts in government spending, as well as inflation-reduction measures initiated by the de la Madrid administration. The constitutional amendment allowing for the re-privatization of the banking sector was announced in May 1990. In August of that year, the finance ministry announced the principles that would inspire the privatization process. Two of the goals of the program were to increase competition and efficiency in the financial system and to improve bank capitalization.

\footnotetext{
${ }^{13}$ Asset-based warehousing firms, or almacenes generales de depósito, stored goods in exchange for certificates of deposit, which could be sold to other credit institutions. See Katz (1990).

${ }^{14}$ See Unal and Navarro (1999).

${ }^{15}$ See Katz (1990).
}

The government took great efforts to guarantee transparency of the process; they indicated that the sale price of the banks would be consistent with valuations based on objective criteria. But the results of these valuations, however, were not made public, and the overvaluation of some banks became obvious after the purchase was completed.

Some studies underscore several problems with the financing schemes that buyers adopted to purchase these banks from the government, which in some cases included borrowing from the same banks they were buying. ${ }^{16}$ These studies seem to agree that the privatization auctions were designed to maximize the purchase price of the banks.

The auctions were conducted from June 1991 through July 1992. Interested parties were allowed to acquire the controlling shares of only one bank, and the privatization was open only to Mexican nationals. There were six rounds of bidding. Packages of three or four banks were sold in each round. The sequencing of the sale was designed to increase competition in subsequent stages of the bidding process. The largest banks were sold in the first rounds. Interestingly, the government provided no minimum bid or reserve price information. ${ }^{17}$ At the end of the process, banks were sold at an average price-to-book value ratio of 3.04, producing about $\$ 12.4$ billion for the government. ${ }^{18}$

Some studies suggest that buyers paid those prices anticipating a concentrated market structure with oligopolistic profits. In fact, of the existing 18 banks, the 4 largest banks controlled 70 percent of total bank assets, and Mexican banks did not face competition from the entry of foreign banks, as they were not allowed to participate in the privatization auctions. ${ }^{19}$

The lack of a competitive market structure in the newly privatized banks was not the only prob-

\footnotetext{
${ }^{16}$ See Unal and Navarro (1999) and Haber (2005b).

${ }^{17}$ See Avalos and Hernández Trillo (2006).

${ }^{18}$ The calculation of the average is weighted by assets. See Murillo (2002) and Unal and Navarro (1999).

${ }^{19}$ See Haber (2005b,c).
} 
lem. More fundamental problems plagued the institutional framework under which the banks were to operate. From the outset of the new privatization era, bankers faced incentives that would encourage inefficient, risky lending.

Haber (2005b,c), for example, argues that at the time of the privatization, Mexico had weak property rights institutions to assess the credit worthiness of borrowers and to enforce the contract rights of bankers. Furthermore, he also argues that out of the privatization process emerged a set of institutions that reduced the incentives of bank directors, bank depositors, and bank regulators to enforce the prudent behavior of the newly privatized banks. Some of these institutions would not be reformed until after the 1995 collapse. This view is shared by Unal and Navarro (1999), who argue that, despite the recent reforms, the new banks operated under an outdated regulatory environment and that the supervisory agencies were often unable to implement newly adopted regulations or to enforce existing rules.

Efficient monitoring both internally and by the government was also lacking. No regulatory body required the banking sector to adhere to the generally accepted accounting principles in international markets. Accounting standards were very lax and, in particular, did not require banks to report the entire value of past-due loans as nonperforming, but only the past-due interest payments; banks were allowed to roll over the principal of those loans. Banks were not required to provide consolidated financial reports until 1995, even though at this time they were operating under a universal banking structure. ${ }^{20}$ This lack of regulation made it difficult to establish limits on lending within financial groups. In addition, the Mexican central bank implicitly guaranteed unlimited deposit insurance through FOBAPROA. There were no credit bureaus, and legal institutions in Mexico did not provide an adequate enforcement of lending contracts.

In contrast with the expectations of an oligopolistic market structure, banks soon were competing for market share. ${ }^{21}$ Credit was growing very

\footnotetext{
${ }^{20}$ See Gonzalez and Marrufo (2001).

${ }^{21}$ See Gruben and McComb (1997).
}

rapidly, and nonperforming loans soon became a problem.

\section{THE BANKING BAILOUT}

\section{Risky Lending Practices}

The December 1994 devaluation and macroeconomic crisis that ensued was not the origin of the banking crisis; it was merely the trigger. ${ }^{22}$ Induced by the lack of an appropriate legal and regulatory environment, banks had been engaged in risky lending practices almost immediately after the privatization process was concluded and past-due loans had been rising dramatically prior to the devaluation.

Several factors-including low inflation, improvements in the fiscal surplus of the government, an exchange rate under a controlled rate of depreciation, and low real interest rates-contributed to an expansion of both bank credit and financial intermediation in general. The size of the financial sector, given by M4 as a share of GDP, reached 47 percent at its peak in $1994 .^{23}$ (See Figure 3.)

From December 1988 to November 1994, credit from local commercial banks to the private sector rose in real terms by 277 percent, or 25 percent per year. ${ }^{24}$ Nonperforming loans, however, grew even faster. Between December 1991 and December 1993 alone, gross past-due loans more than tripled in absolute terms, while the share of reported nonperforming loans to total loans rose from 4.13 to 7.26 percent. ${ }^{25}$ This situation per-

\footnotetext{
22 After a failed attempt of a controlled devaluation on December 20, 1994, a run against the peso led to the collapse of the semi-fixed exchange rate regime and the peso was allowed to float on December 22, 1994. For a detailed account of the events and an analysis of the factors contributing to the vulnerability of Mexico's financial sector, see Calvo and Mendoza (1996) and Gil-Díaz (1998), and also Gruben and McComb (1997).

${ }^{23}$ M4 is a broad monetary aggregate defined as M3 + deposits in branches of domestic banks abroad, where M3 = M2 + domestic financial assets held by non-residents, $\mathrm{M} 2=\mathrm{M} 1+$ domestic financial assets held by residents, and M1 = currency outside of banks, domestic and foreign currency checking accounts in resident banks, domestic and foreign currency current account deposits in resident banks, and sight deposits in savings and loan associations.

${ }^{24}$ See Gil-Díaz (1998).

${ }^{25}$ See Gruben and McComb (2003).
} 


\section{Figure 3}

\section{Size of the Financial Sector: M4}

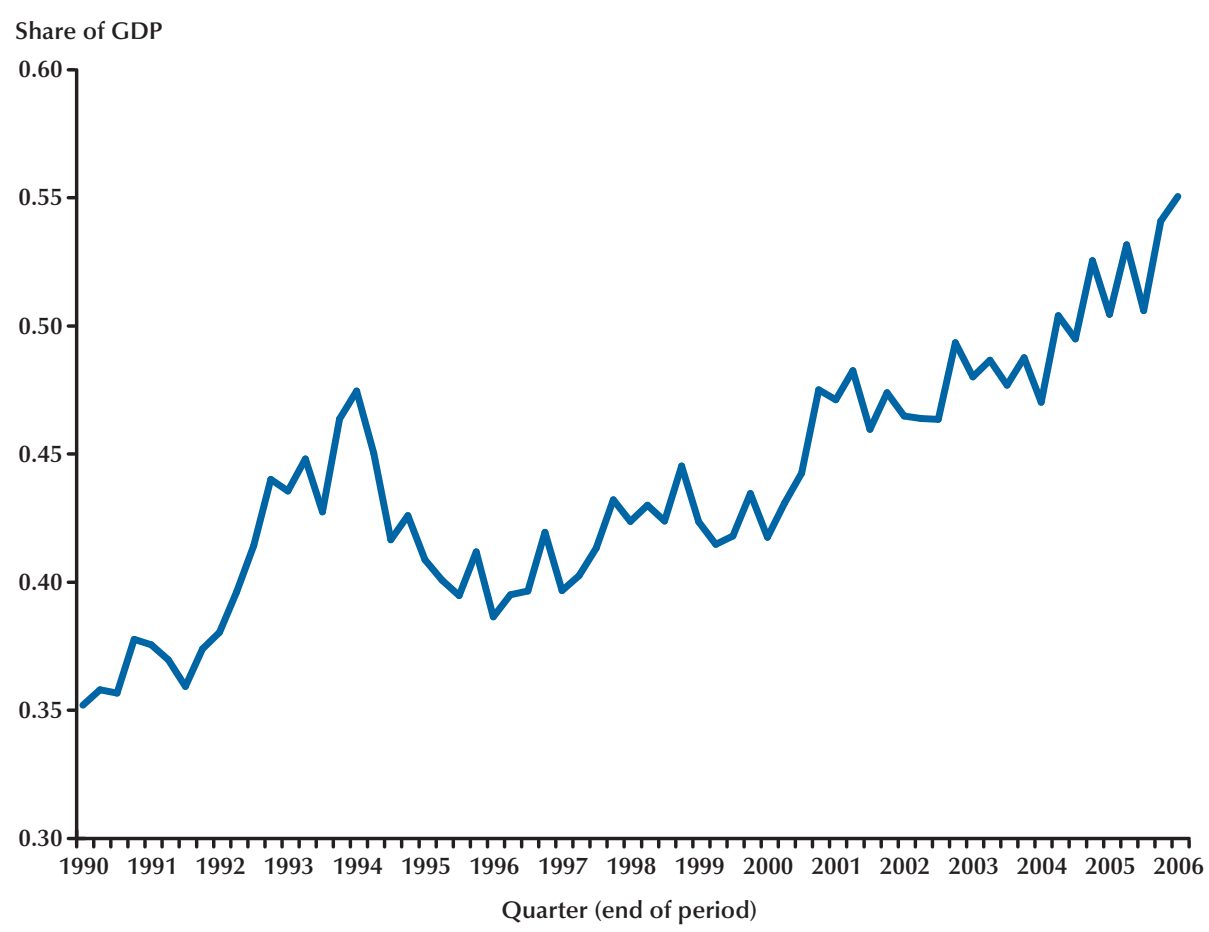

SOURCE: Banco de México.

sisted into the bailout episode that followed. Haber (2005b) estimates that, as of December 1991, the ratio of nonperforming loans to total loans (including principal rollovers and the value of loans transferred to FOBAPROA) was 13.5 percent; it increased to 17.1 percent by December 1994, to 36.3 percent by December 1995, and to 52.6 percent by December of 1996 .

An example of risky lending behavior was related lending, a topic studied by La Porta, López de Silanes, and Zamarripa (2003). Related lending refers to the practice of lending to separate firms in which bank officials have interests either because they own these other firms or their associates or family members do. In their study, the authors tracked a sample of loans outstanding at Mexican banks from the end of 1995 through 1999. They found that about 20 percent of loans were to related parties. They also found that these parties were more likely to borrow at lower rates, were less likely to post collateral, and were more likely to default than unrelated parties. The authors examined the regulations set forth after the 1990 privatization and noted that very few rules addressed conflicts of interest arising from lending to related parties. The authors identified other key factors, beyond regulation of conflict of interests, that provided incentives to engage in risky lending policies: the universal guarantees provided by FOBAPROA (which guaranteed all deposits up to 100 percent, regardless of the creditworthiness of the bank and the total amount of deposits) and the minimal capitalization requirements imposed on the banks (which were unrelated to the riskiness of the bank's loan portfolio). So, because of the presence of deposit insurance, the lower a bank's capital, the greater its incentive was to take on additional risk because 


\section{Figure 4}

\section{Inflation}

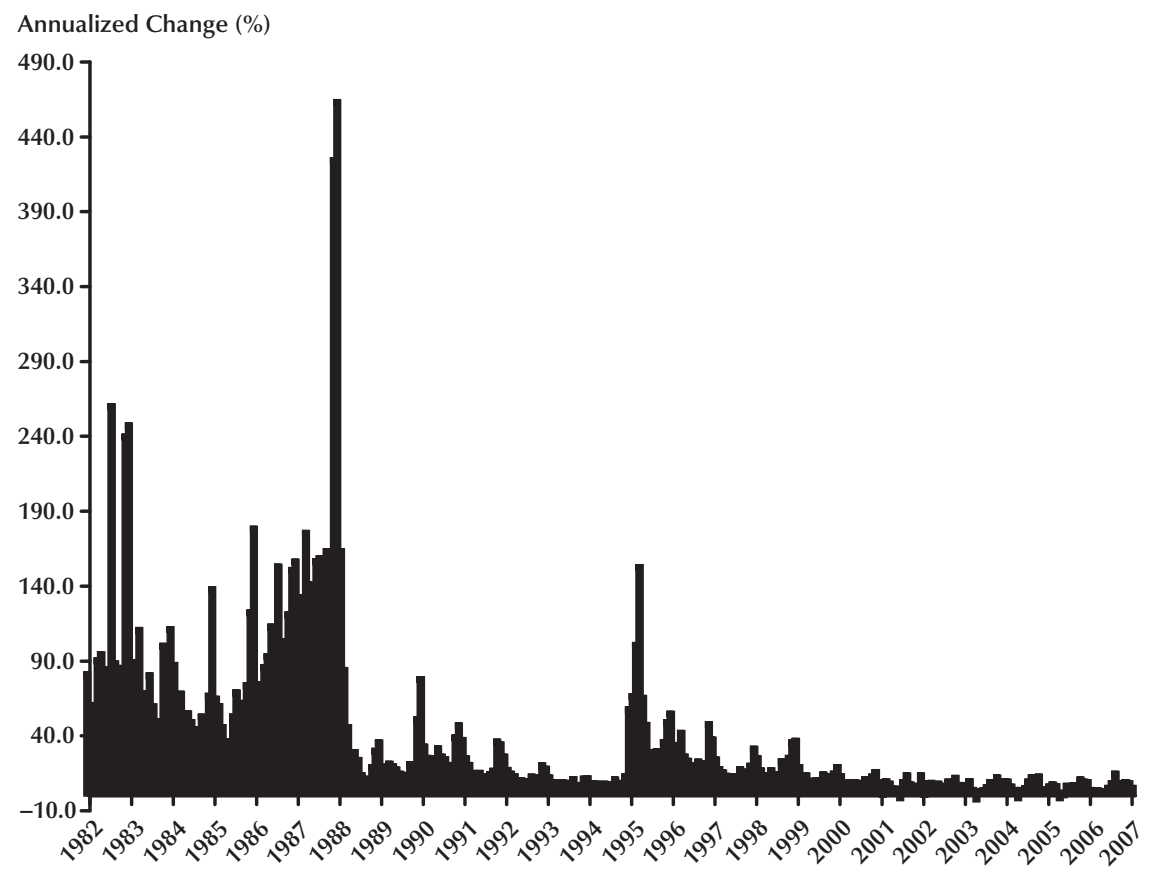

SOURCE: Banco de México.

less of their own wealth was at stake. ${ }^{26}$ La Porta, López de Silanes, and Zamarripa (2003) argued that banks engaged in excessive related lending because of moral hazard: Legally, bank assets were considered separate from the related firm's assets and regulatory authorities were insuring these loans, too. ${ }^{27}$

\section{The Rescue Program}

The devaluation of December 1994 generated capital outflows and high inflation. Real GDP declined by 6.2 percent in 1995, while the annualized inflation rate reached 46.9 percent in December 1995. (See Figures 2 and 4, respectively.) The central bank imposed restrictive credit

${ }^{26}$ See Furlong and Keeley (1989) and Keeley (1990).

${ }^{27}$ For additional literature on the moral hazard problems generated by deposit insurance institutions, see Demirgüç-Kunt and

Detragiache (2002), Cull, Senbet, and Sorge (2005), and also Martin (2006), as well as references therein. and monetary policies in February 1995, and interest rates skyrocketed. Many borrowers were unable to repay their loans. The rising level of past-due loans had put the banking system at the brink of total collapse. ${ }^{28}$

Three regulatory authorities intervened in the design and implementation of the rescue package that started in 1995 and continued through December 1998. The first was Mexico's central bank, Banco de México. The second authority was Mexico's finance ministry, Secretaría de Hacienda y Crédito Público, which is the main financial authority in Mexico ultimately responsible for regulating and supervising the entire financial system. These tasks, however, are delegated to the third regulatory authority, the national banking and securities commission, Comisión Nacional Bancaria y de Valores, which regulates

${ }^{28}$ See Gruben and McComb (1997) and McQuerry (1999). 
and supervises all financial intermediaries in Mexico. ${ }^{29}$

The Mexican government adopted several measures to prevent the collapse of the banking system, including efforts to improve banks' immediate liquidity requirements following the December 1994 devaluation, measures to improve capitalization, various debtor relief efforts, and ultimately the transfer of nonperforming loans into public debt, approved by the Mexican Congress in December 1998. The funding of these programs was channeled through the nation's bank deposits insurance institution, whose liabilities amounted to about $\$ 60$ billion in February 1998 near the end of the rescue program and represented almost five times the amount received by the government when banks were privatized. ${ }^{30}$

I now review some of the specific programs included in the rescue package that followed the 1995 crisis.

Liquidity Window. After the December 1994 devaluation, several banks were unable to roll over their dollar-denominated liabilities. During 1995, the central bank offered short-term dollardenominated credit through FOBAPROA so that banks could meet immediate dollar liabilities. The terms of these loans were designed so banks could soon find alternative funding sources. The program served its purpose, and all banks that received these loans repayed them.

Initial Capitalization Program. In February 1995, the government created a special short-term recapitalization program that would allow banks to raise capital by selling 5-year convertible bonds to FOBAPROA. The goal was to help banks increase their capital-to-assets ratio above 8 percent while they tried to raise additional capital on their own. ${ }^{31}$ The program included reforms that removed restrictions on the ways banks could increase capital. Banks were charged higher interbank interest rates and were prohib-

\footnotetext{
${ }^{29}$ Prior to 1995 , the banking and securities commissions were two separate agencies.

${ }^{30}$ See Hernández Trillo and López Escarpulli (2001).

${ }^{31}$ This was the minimum capitalization ratio recommended by the Basel I accords.
}

ited from issuing other subordinated debt until they exited the program. The program was not entirely successful, as many banks avoided participation, motivated in part because the market seemed to interpret participation as a sign of weakness and imminent regulatory intervention by the authorities. ${ }^{32}$ Many banks tried to raise capital on their own and failed to attain the capitalization requirements.

Loans for Bonds Swaps. The core program in the rescue package had the goal of preventing generalized failure in the banking system. With this program, FOBAPROA initially acquired only a portion of past-due loans from commercial banks and acquired the rights to any payments that could be recovered by the banks. ${ }^{33}$ In exchange, banks had to purchase FOBAPROAissued special 10-year non-negotiable bonds backed by Mexico's central bank. Banks were also required to raise new capital at the rate of one peso for each two pesos of loans transferred to FOBAPROA. Additionally, FOBAPROA bonds were indexed in a new unit of account (referred to as UDI or Unidad de Inversión) created in 1995, which was indexed to the inflation rate to guarantee the real value of funds. When the maturities of these bonds were reached, banks would be allowed to either roll over the debt or sell it. Mortgage loans were also included in the rescue package.

Participating banks agreed to surrender their institutions to banking authorities if they were unable to convert their debt with FOBAPROA into equity capital. ${ }^{34}$ Some banks were unable to raise additional capital, and FOBAPROA undertook further capitalization efforts to help these banks. These efforts allowed banks to continue to operate. When FOBAPROA determined that a bank was no longer viable, the bank would be liquidated and its assets would be sold. Banks acquiring these assets would also take over the bank's liabilities, which were backed by matching loans from FOBAPROA.

\footnotetext{
32 See Mackey (1999).

${ }^{33}$ Later, as past-due loans continued to rise, more loans were also included in the rescue package.

${ }^{34}$ See McQuerry (1999).
} 
The national banking commission had the right to formally intervene in cases of irregular practices, which ranged from failure to meet reserve and capitalization requirements to illicit operations and fraud: The authorities would take control of the bank's management and suspend stockholder privileges while the investigations were ongoing. Meanwhile, FOBAPROA continued to support these banks in their capitalization efforts. By June 1998, the authorities had intervened in the operations of 12 banks. Two of these, Banca Cremi and Banco Unión, were under the authorities' control prior to the peso devaluation. Additionally, several banks, including Banca Serfín, Mexico's third largest bank, underwent de facto intervention and were subjected to a more strict supervisory process, which included many of the controls used in a formal intervention. ${ }^{35}$

NAFTA and Foreign Banks. As part of the rescue program, early in 1995, the government also allowed foreign investors to purchase a troubled bank, if that bank accounted for no more than 6 percent of total Mexican bank capital; but these foreign entities were not allowed to start new banks yet. This reform legalized the purchase of all but the three largest banks. ${ }^{36}$ The new law also raised the maximum amount of banking capital that could be controlled by foreign banks to 25 percent, compared with the previous limit of 9 percent initially allowed by NAFTA in 1994.

Debt Relief Programs. Throughout the 199598 banking bailout episode, there were several debt relief programs designed to provide support to small borrowers (individually or in specific industry sectors) and help them repay their bank loans. Some programs were financed by the government and others involved negotiations among the banks and their borrowers. All these programs were supervised by the national banking commission.

These programs included features such as reduced interest rates, payment discounts, and debt restructuring into the newly created inflationindexed accounting unit with a fixed real interest rate. Debtors were responsible for repaying the

\footnotetext{
${ }^{35}$ See Mackey (1999).

${ }^{36}$ See Gruben and McComb (1997).
}

real interest rate, while the government covered the difference between the nominal and real interest rates.

Mackey (1999) found that these debt relief programs succeeded in helping a large number of small debtors repay their loans. The overall impact on these programs on total past-due loans was most probably minimal. However, Mackey (1999) argues that in designing these programs, the authorities were more interested in preventing generalized runs against the banking system caused by lack of depositors' trust.

\section{POST-CRISIS FINANCIAL REFORMS}

Since 1995 the national banking commission has sought the advice of U.S. government agencies, such as the Federal Reserve and the Office of the Comptroller of the Currency, as well as international organizations, such as the World Bank and the International Monetary Fund, to improve its regulatory practices (Mackey, 1999). The Mexican government has also striven since 1997 to align these practices with international standards, particularly with regard to banking accounting standards, capitalization requirements, and credit risk qualifications; it has also enacted reforms since then to improve bankers' incentives, including changes to FOBAPROA and reforms to bankruptcy and mortgage laws, as well as the promotion of private credit bureaus.

\section{Bank Accounting Standards and Supervision Practices}

New bank accounting standards in Mexico were approved by the banking regulatory authority in December of 1995 and were adopted in January 1997. ${ }^{37}$ The new criteria imposed greater disclosure on banks and made their balance sheets more directly comparable with those in other countries, particularly with regard to the disclosure of nonperforming loans. The new rules also required consolidated balance sheets and income statements for financial groups.

\footnotetext{
${ }^{37}$ See Mackey (1999), McQuerry and Espinosa (1998), and Del Ángel, Haber, and Musacchio (2006).
} 
As related earlier, one of the problems that led to the banking crisis of 1995 was the lack of strict disclosure rules regarding nonperforming loans. Banks calculated nonperforming loans with a due payments criteria; that is, only loan payments 90-days past due were recorded as nonperforming, as opposed to classifying as nonperforming the value of the entire loan itself. All the while, the outstanding balance could still accrue interest. In addition, if loans were restructured or renegotiated, the loan was reclassified as a new loan. As a result of these practices, a bank's income statement and its capital adequacy ratios did not reflect accurate information about the bank's financial health. ${ }^{38}$

Under the new laws, the value reported as past due was now the total unpaid balance of the loan, and loans were listed as nonperforming after a set number of payments went unpaid. The new criteria also required more strict provisions for loan losses, and interest could no longer be accumulated.

The new laws also set stricter standards to deal with related lending. In particular, a bank was required to inform the banking regulatory authority of all the details of a related loan, after the loan was approved by a majority of the bank's directors. Limits were also set on the total amount of loans made to related parties. ${ }^{39}$

In 1999, the banking authorities also established new rules for the assessment and measurement of risks; these rules were strengthened in 2003 to conform with recommendations on capital adequacy and contingency reserve requirements from the Basel II accords.

\section{Reforms to FOBAPROA}

In December 1998, Mexico's deposit insurance institution, FOBAPROA, was replaced by a new entity, the Institute for the Protection of Bank Savings, or IPAB. This institution is now responsible for insuring bank deposits and managing bank support programs. It differs from FOBAPROA in several aspects and is more similar in design

\footnotetext{
${ }^{38}$ See Gil-Díaz (1998).

${ }^{39}$ See Mackey (1999).
}

to other international deposits insurance institutions, such as the Federal Deposit Insurance Corporation in the United States. This new institution is designed to offer more protection to small depositors and allows larger depositors to face more risk. In particular, whereas FOBAPROA offered implicitly unlimited guarantees on deposits, IPAB offers limited guarantees explicitly. IPAB also has the authority to formally intervene if it detects irregularities in a member bank, although the authority of the national banking commission supersedes that of the IPAB.

In 2005, regulations established an upper bound on the total amount of insured deposits of 400,000 UDIs (about $\$ 100,000$ at the thenprevailing exchange rate) per individual or business by bank. ${ }^{40}$ In general, the reason to limit deposit-insurance coverage is to encourage depositors with large balances to monitor bank behavior and thereby establish a better link between deposit interest rates and balances and a bank's risk taking.

\section{Bankruptcy Laws}

Before the re-privatization, Mexican laws on bankruptcy and debt moratory dated back to 1943. A reform in 1988 created special bankruptcy courts to deal with business bankruptcies, which fell within the purview of federal legislation; personal bankruptcies, in contrast, were legislated at the state level and dealt with in state civil courts. In spite of these reforms, bankruptcy cases in Mexico continued to be notoriously lengthy and complex, as the laws generally provided little incentives for the repayment of debts. As a consequence, lenders often faced difficulties recovering assets from insolvent borrowers. In addition, there were not enough such bankruptcy courts. Banks often settled negotiations with debtors outside of the courts, with great advantages to the latter. ${ }^{41}$

On April 25, 2000, a new law was approved by the lower house of the Mexican Congress that would replace existing bankruptcy laws for per-

\footnotetext{
${ }^{40}$ See Haber (2005a).

${ }^{41}$ See Mackey (1999).
} 
Figure 5

\section{Bank Credit to Private Sector}

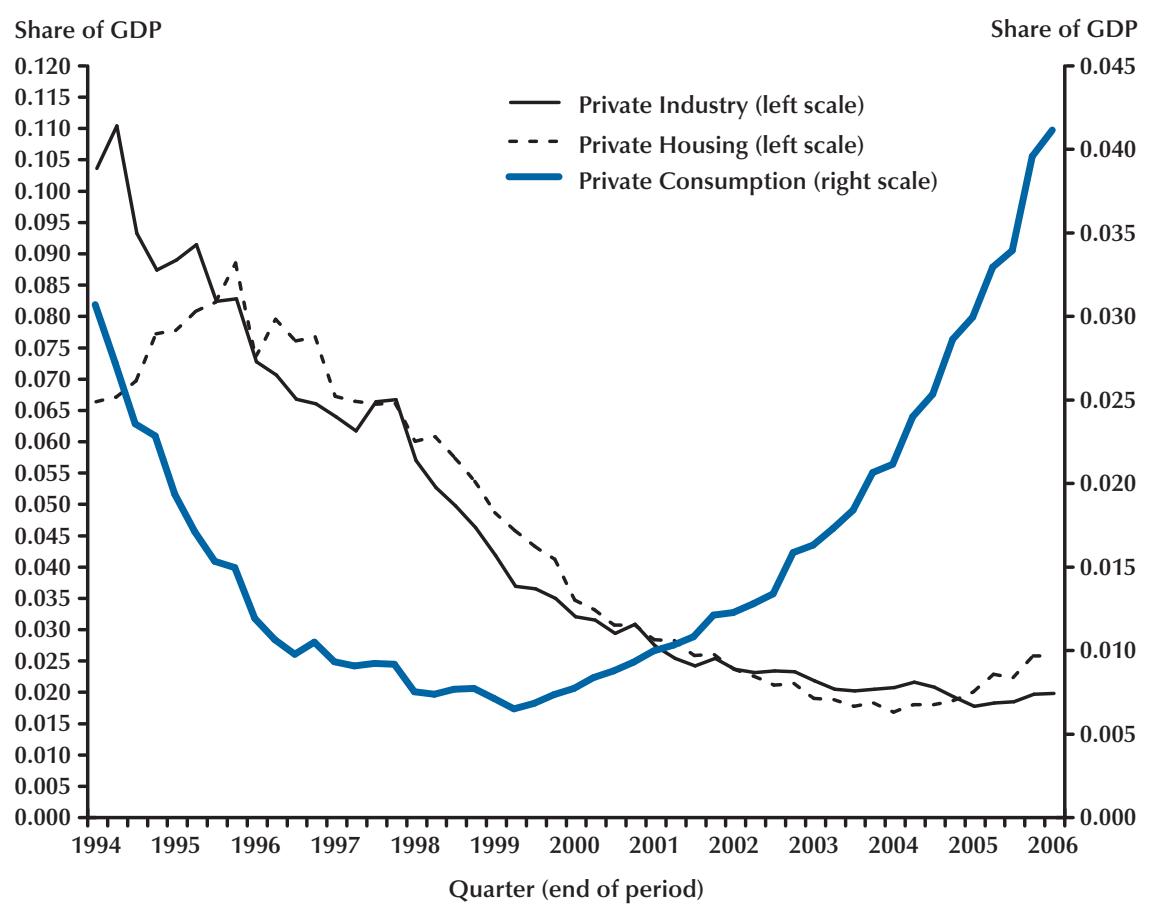

SOURCE: Banco de México.

sons and businesses. It seems, however, that this new law still falls short in terms of providing banks with adequate repayment guarantees. ${ }^{42}$

\section{Mortgage Markets}

After the 1995 crisis, mortgage lending by commercial banks plummeted along with total private lending, and banks all but exited the housing lending market. (See Figure 5.) New financial associations with limited functions (known in Mexico as SOFOLES) had been created in 1993 to foster competition in the financial system; after the 1995 crisis, these non-bank financial intermediaries became important players in the lowincome mortgage market.

These non-bank banks borrowed funds from government development banks as well as from

42 See Hernández Trillo and López Escarpulli (2001) and Avalos and Hernández (2006). private commercial banks; in turn they gave loans to consumers to purchase homes and autos but were initially prohibited from accepting deposits or investing in securities or derivatives. ${ }^{43}$

In recent years, the role of non-bank banks in providing financing services to the private sector has increased remarkably. From 2000 to 2006 the share of total loans to the private sector provided by non-bank banks increased from 6.3 percent to 9.1 percent. In real terms, total loans by these intermediaries grew by about 130 percent. ${ }^{44} \mathrm{By}$ December 2006, there were 56 non-bank banks. The largest share of total loans granted by these institutions has been for private housing, reaching about 42 percent by December 2006. The nextlargest categories are loans to private industry

\footnotetext{
43 See Haber and Musacchio (2005).

${ }^{44}$ Data through September 2006. Source: Secretaría de Hacienda y Crédito Público.
} 
(37 percent) and for private consumption (18 percent). ${ }^{45}$

Mortgage markets in Mexico are currently undergoing a very remarkable transformation. From 2001 to 2006, the average compound annual growth rate of housing loans was 27.3 percent; in 2006, these loans amounted to about $\$ 79.6$ billion. ${ }^{46}$ Bank lending for private housing began to increase in 2004. (See Figure 5.)

From 1995 to 2002, two government institutions provided most of the funding to non-bank banks; since about 2003, however, mortgage origination by non-bank banks and commercial banks has been funded largely by other sources. ${ }^{47}$

Non-bank banks, investment banks, and the Federal Mortgage Association had been pushing forward the securitization of mortgage-backed bonds to develop a secondary market, which started in 2003, when the first mortgage-backed security was issued for $\$ 178$ million. ${ }^{48}$

In 2006, the first commercial bank entered this market. Also in 2006, a new unified property registry began operations in Mexico. Its objective has been to concentrate records for all the existing housing supply as well as new starts that can be purchased with funding by private and public mortgages lenders. By maintaining updated information, which can be used by developers, lenders, and consumers, the registry is expected to help improve efficiency and boost the development of housing and mortgage markets.

In 2007, Mexico's Federal Mortgage Association, in association with the Netherlands Development Finance Company, created a new company called HiTo to provide a bridge between mortgage lending and the bond market by standardizing mortgage-backed securities into large pools, with the goal of increasing liquidity and efficiency in the market. ${ }^{49}$

\footnotetext{
${ }^{45}$ Source: Comisión Nacional Bancaria y de Valores.

${ }^{46}$ See www.shf.gob.mx/files/pdf/Estrategia\% 202007-2013.pdf.

${ }^{47}$ The first government mortgage institution is a trust for lowerincome housing whose liabilities are funded by Mexico's central bank, the World Bank, and other sources (see Pickering, 2000). The second institution is the Federal Mortgage Association created in 2001 to promote the development of a secondary mortgage market.

${ }^{48}$ See Skelton (2006).

${ }^{49}$ See The Economist (2007).
}

\section{Credit Bureaus}

A credit bureau operated by the central bank has existed in Mexico since 1964, but it was only for business loans and was rarely used. ${ }^{50}$ From 1993 to 1998, Mexican regulatory authorities laid the framework for the existence of private credit bureaus, which was designed to improve the way individuals' credit history information was collected. ${ }^{51}$ Additional laws to regulate the credit bureaus were passed in 2002 and 2004.

The goal of credit bureaus is to improve credit screening and assessment of repayment capabilities of individuals and firms. Starting in 1998, the banking commission has required banks to establish reserves for 100 percent of those loans in which borrowers are found to have poor or no credit history. ${ }^{52}$

Since 1995, three firms have entered the market; but today only one, Buró de Crédito, remains, and it now tracks the credit histories of both consumers and businesses.

\section{Increased Participation of Foreign Banks}

Some of the most remarkable developments that followed the 1995 crisis were the reforms that allowed for increased foreign ownership of commercial banks. Today, foreign participation has essentially rebuilt the sector, improving capitalization and the quality of bank assets and contributing to the accelerated decline of bad loans. Since 2004, foreign participation has helped to increase bank credit in the economy. (See Figures 1 and 5.)

In 1994, NAFTA allowed foreign-owned banks to operate in Mexico, although there remained severe restrictions on the market share that foreign banks were allowed to control. NAFTA also restricted the equity share controlled by foreign nationals on Mexican banks. By 1994 there were 35 banks in the system, and only 2 banks, which

\footnotetext{
${ }^{50}$ See Gil-Díaz (1998).

${ }^{51}$ See Negrin (2001).

52 See Mackey (1999).
} 
Table 1

Commercial Bank Assets as of December 2006

\begin{tabular}{|c|c|c|c|}
\hline Bank name & Assets (million pesos) & Share of total & Foreign control \\
\hline All banks total & $2,564,279.8$ & 100.0 & \\
\hline BBVA Bancomer & $600,836.3$ & 23.4 & Yes \\
\hline Banamex & $538,881.1$ & 21.0 & Yes \\
\hline Santander & $402,075.2$ & 15.7 & Yes \\
\hline $\mathrm{HSBC}$ & $284,045.4$ & 11.1 & Yes \\
\hline Mercantil del Norte & $209,031.9$ & 8.2 & No \\
\hline Scotiabank Inverlat & $127,150.0$ & 5.0 & Yes \\
\hline Inbursa & $80,800.3$ & 3.2 & No \\
\hline I.N.G. Bank & $57,980.6$ & 2.3 & Yes \\
\hline Del Bajío & $46,131.4$ & 1.8 & No \\
\hline Banco Azteca & $44,088.5$ & 1.7 & No \\
\hline J.P. Morgan & $31,911.9$ & 1.2 & Yes \\
\hline Bank of America & $16,609.3$ & 0.7 & Yes \\
\hline IXE & $15,226.0$ & 0.6 & No \\
\hline Interacciones & $12,881.2$ & 0.5 & No \\
\hline Afirme & $11,438.6$ & 0.5 & No \\
\hline American Express & $10,707.5$ & 0.4 & Yes \\
\hline Invex & $10,345.7$ & 0.4 & No \\
\hline Banregio & $9,720.7$ & 0.4 & No \\
\hline G.E. Capital & $9,598.3$ & 0.4 & Yes \\
\hline Mifel & $7,581.5$ & 0.3 & No \\
\hline BBVA Bancomer Servicios & $5,982.1$ & 0.2 & Yes \\
\hline Deutsche Bank & $5,880.9$ & 0.2 & Yes \\
\hline Ve por más & $4,890.2$ & 0.2 & No \\
\hline Bansí & $4,264.5$ & 0.2 & No \\
\hline Credit Suisse & $3,614.5$ & 0.1 & Yes \\
\hline Compartamos & $3,283.8$ & 0.1 & No \\
\hline A.B.N. Amro Bank & $3,269.9$ & 0.1 & Yes \\
\hline Barclays Bank & $2,728.5$ & 0.1 & Yes \\
\hline Tokio-Mitsubishi UFJ & $2,402.4$ & 0.1 & Yes \\
\hline Monex & 569.7 & 0.0 & No \\
\hline Autofín & 352.0 & 0.0 & No \\
\hline
\end{tabular}

SOURCE: Assets are from Boletín Estadístico de Banca Múltiple, Comisión Nacional Bancaria y de Valores, December 2006, www.cnbv.gob.mx. 
provided retail lending, were controlled by foreign ownership. ${ }^{53}$

By December 1996, only 7 percent of total bank assets were controlled by foreign banks, but this share increased to 11 percent by December 1997 after all the restrictions were removed. By December 1999, 20 percent of bank assets were controlled by foreign banks; by December 2004, 83 percent of bank assets in Mexico were controlled by foreign banks. ${ }^{54}$ As of December 2006, foreign banks still controlled about 82 percent of total bank assets. (See Table 1.)

Haber and Musacchio (2005) argue that the entry of foreign banks has increased competitive pressures, which have improved efficiency in the sector, even among those banks not controlled by foreign banks. They find that, while foreign entry between 1997 and 2004 improved the profitability of the sector, foreign banks were not more profitable, on average, than domestic banks, although foreign banks may have been initially better at screening borrowers. Schulz (2004) has also found that increased entry of foreign banks has helped improve various measures of productivity in the sector.

The entry of foreign banks in the sector has been instrumental to the recovery of bank credit, which had plunged after the 1994 devaluation. Total credit by commercial banks declined from about 40 percent of GDP in the fourth quarter of 1994 to about 13 percent in the first quarter of 2004. Similarly, bank credit to the private sector declined from about 37 percent of GDP in the fourth quarter of 1994 to about 9 percent in the first quarter of 2004. (See Figure 1.)

In contrast to total bank credit, credit for private consumption started recovering soon after the bank rescue program was completed in 1999, reflecting in part an increase in the use of credit cards. Other types of bank credit to the private sector-in particular, housing loans-would not begin to recover until 2004. Bank credit to the private industry, however, still remains stagnant at about 2 percent of GDP. (See Figure 5.)

\footnotetext{
${ }^{53}$ See Bubel and Skelton (2005) and also Haber (2005b).

${ }^{54}$ See Haber (2005c) and also Haber and Musacchio (2005).
}

The recovery in private bank credit, driven by entry of foreign banks, has produced significant welfare gains (in the form of lower net interest margins) among Mexican consumers. ${ }^{55}$ The entry of foreign banks has also generated positive effects on banks' productivity and capitalization derived from the increase in foreign capital, and the improvement in bank asset quality has helped accelerate the reduction of bad loans in the banking system. ${ }^{56}$

FOBAPROA/IPAB bonds had begun to mature by the end of 2005 and are now being rolled over into negotiable bonds, which will provide banks with additional liquidity to lend to the private sector. The cumulative effects of Mexico's reforms in the financial system, including the widespread presence of foreign banks in the sector, suggest that the recent reversal in bank credit will continue. ${ }^{57}$

\section{WAL-MART'S BANK IN MEXICO}

In November 2006, Wal-Mart's subsidiary in Mexico received approval to open a bank and became the second retail chain in Mexico to operate a bank. The first, Grupo Elektra, has been operating a full-service bank, Banco Azteca, since 2002. In 2006, other retailers also applied for and received licenses to operate banks. The stated goal of both Wal-Mart's and Elektra's banks is to provide banking services to Mexico's low-income individuals, who have traditionally faced barriers to loans from commercial banks or have chosen not to maintain checking or savings accounts because of steep maintenance fees. Elektra, whose retail operations include mostly consumer electronics and home appliances, for example, provided consumer loans for about five decades before creating a commercial bank.

Wal-Mart entered the retail chain market in Mexico in 1991 when the first Sam's Club opened in December. In 1992, Wal-Mart started an alliance with Grupo Cifra, which controlled a successful chain of retail stores. In 1993, Wal-Mart's first

\footnotetext{
${ }^{55}$ See Haber and Musacchio (2005).

${ }^{56}$ See Schulz (2004).

${ }^{57}$ See Bubel and Skelton (2005).
} 
Supercenter opened, and more companies (a chain of restaurants and a chain of clothing stores) joined the alliance with Cifra. Wal-Mart quickly gained market share and in 1997 bought a controlling stake in Grupo Cifra. By 2001, Wal-Mart de México controlled about half of all supermarket sales in the country. In 2006 alone, 120 stores were opened and total sales reached about $\$ 18.3$ billion, an inflation-adjusted increase of 15.9 percent over 2005 sales. ${ }^{58}$ Today, Wal-Mart is Mexico's largest private employer, with 149,584 employees; it owns 917 stores in 147 cities, which include supermarkets, restaurants, and clothing stores.

Wal-Mart's banking experiment is interesting because of the regulatory environment it will face in Mexico. Gelpern (2007) notes that all other foreign banks in Mexico, although established by law as wholly owned and separately capitalized subsidiaries, have parent institutions that are themselves regulated and subject to supervision by their home country authorities. Given Wal-Mart's failed attempts to enter the banking sector in the United States, Wal-Mart's bank in Mexico remains its only banking venture in the world, and therefore the Mexican authorities will have sole responsibility over its regulation and supervision, while Wal-Mart's headquarters in the United States will remain outside of Mexican authorities' regulatory scope. Gelpern warns, however, that although the banking license establishes limits to the ties between Wal-Mart's banking and retail businesses, Mexico's limited leverage over Wal-Mart activities outside of Mexico puts Wal-Mart in a unique position to demand support from Mexican authorities. This, Gelpern argues, is because of Wal-Mart's strength in the retail sector, because no other foreign bank has retail stores, and because other retail chains with banks are currently owned by Mexican nationals and therefore subject entirely to Mexican laws.

Thus far, Wal-Mart's strategy in entering the banking sector appears to be similar to Elektra's: first, approach customers who have traditionally avoided the banking sector; afterwards, expand

\footnotetext{
58 Source: sales and store counts from www.walmartmexico.com.mx; United States-Mexico exchange rate as of December 2006 from research.stlouisfed.org/fred2/data/EXMXUS.txt.
}

to middle-income consumers. The effects of Wal-Mart's entry on banking competition are yet to be seen. However, Wal-Mart's entry into the banking sector should provide for an interesting environment in the very immediate future: Despite the improved conditions in the sector, Mexican consumers still face high fees for banking services, and Wal-Mart may extend its traditionally aggressive low-pricing strategy to its banking business.

\section{WHAT NEXT?}

Apart from recent favorable developments in Mexico's bank credit, at its core, the country still faces fundamental problems with its legal infrastructure. Property rights in Mexico were until very recently not well defined and in many cases continue to be poorly enforced. ${ }^{59}$ Even today, it is difficult even to ascertain who owns a particular asset (recall that a unified property registry was not put in place until 2006); and, as a consequence, it is still difficult for banks to repossess assets given as collateral in a loan. Haber (2005c) argues that, as long as these institutional problems are not resolved, they will continue to limit the type of contracts that bankers can enforce. Haber's view reflects the notion that the protection of property rights has positive effects on long-run economic performance, a notion that is widely recognized by economists. (See, for example, Acemoglu and Robinson, 2000; Acemoglu, Johnson, and Robinson, 2002; and, more recently, Gradstein, 2007, among others.) It would seem, then, that Mexico stands to gain from continuing to foster the development of its banking sector and, as a long-run goal for its overall development, modernize its legal infrastructure, especially contract enforcement and the definition and defense of private property rights.

\section{REFERENCES}

Acemoglu, Daron; Johnson, Simon and Robinson, James A. "Reversal of Fortune: Geography and

\footnotetext{
${ }^{59}$ For an analysis of property rights in the Mexican Constitution, see also Katz (1998).
} 
Institutions in the Making of the Modern World Distribution." Quarterly Journal of Economics, November 2002, 117(4), pp. 1231-94.

Acemoglu, Daron and Robinson, James A. "Why Did the West Extend the Franchise? Democracy, Inequality, and Growth in Historical Perspective.” Quarterly Journal of Economics, November 2000, 115(4), pp. 1167-99.

Avalos, Marcos and Hernández Trillo, Fausto. "Competencia Bancaria en México.” Naciones Unidas. Comisión Económica para América Latina (CEPAL), November 2006, Serie Estudios y Perspectivas 62. México.

Bubel, Robert V. and Skelton, Edward C. "Financial Globalization: Manna or Menace? The Case of Mexican Banking." Federal Reserve Bank of Dallas Southwest Economy, January/February 2002, 9(1), pp. 17-19.

Bubel, Robert V. and Skelton, Edward C. "Mexico Emerges from 10-Year Credit Slump.” Federal Reserve Bank of Dallas Southwest Economy, May/June 2005, 12(3), pp. 14-18.

Calvo, Guillermo A. and Mendoza, Enrique G. “Mexico’s Balance-of-Payments Crisis: A Chronicle of a Death Foretold." Journal of International Economics, November 1996, 41(3-4), pp. 235-64.

Cull, Robert; Senbet, Lemma W. and Sorge, Marco. "Deposit Insurance and Financial Development." Journal of Money, Credit, and Banking, February 2005, 37(1), pp. 43-82.

Del Ángel, Gustavo A.; Haber, Stephen and Musacchio, Aldo. "Normas Contables Bancarias en México. Una Guía de los Cambios para Legos Diez Años Después de la Crisis Bancaria de 1995.” El Trimestre Económico, October-December 2006, 73(4), pp. 903-26.

Demirgüç-Kunt, Asli and Detragiache, Enrica. “Does Deposit Insurance Increase Banking System Stability? An Empirical Investigation.” Journal of Monetary Economics, October 2002, 49(7), pp. 1373-406.
Economist. "A Danish Model in Aztec Dress." January 6, 2007, 382(8510), pp. 62.

Furlong, Frederick T. and Keeley, Michael C. "Capital Regulation and Bank Risk Taking: A Note." Journal of Banking and Finance, November 1989, 13(6), pp. 883-91.

Gelos, R. Gaston and Werner, Alejandro M. "Financial Liberalization, Credit Constraints, and Collateral: Investment in the Mexican Manufacturing Sector.” Journal of Development Economics, February 2002, 67(1), pp. 1-27.

Gelpern, Anna. "Wal-Mart Bank in Mexico: Money to the Masses and the Home-Host Hole." Connecticut Law Review, May 2007, 39(4), pp. 1513-38.

Gil-Díaz, Francisco. “The Origin of Mexico’s 1994 Financial Crisis.” Cato Journal, Winter 1998, 17(3), pp. 303-13.

Gonzalez-Anaya, José Antonio and Marrufo, Grecia M. “Financial Market Performance in Mexico." Center for Research on Economic Development and Policy Reform, Stanford University, 2001.

Gradstein, Mark. "Inequality, Democracy and the Protection of Property Rights.” Economic Journal, January 2007, 117(516), pp. 252-69.

Gruben, William C. and McComb, Robert P. "Liberalization, Privatization, and Crash: Mexico's Banking System in the 1990s." Federal Reserve Bank of Dallas Economic Review, First Quarter 1997, pp. 21-30.

Gruben, William C. and McComb, Robert P. "Privatization, Competition, and Supercompetition in the Mexican Commercial Banking System." Journal of Banking and Finance, February 2003, 27(2), pp. 229-49.

Haber, Stephen. "Banking With and Without Deposit Insurance: Mexico’s Banking Experiments 18842004." Unpublished manuscript, Stanford University, 2005a.

Haber, Stephen. “Mexico’s Experiments with Banking Privatization and Liberalization, 1991-2003." 


\section{Hernández-Murillo}

Journal of Banking and Finance, August-September 2005b, 29(8-9), pp. 2325-53.

Haber, Stephen. "Why Institutions Matter: Banking and Economic Growth in Mexico." Unpublished manuscript, Stanford University, 2005c.

Haber, Stephen and Musacchio, Aldo. "Foreign Banks and the Mexican Economy, 1997-2004." Unpublished manuscript, Stanford University, 2005.

Hernández Trillo, Fausto and López Escarpulli, Omar. "La Banca en México, 1994-2000." Economía Mexicana, Nueva Época, 2001, 10(2), pp. 363-90.

Katz, Isaac. El Sistema Financiero Mexicano: Motor Del Desarollo Económico. México: Diana and Centro de Investigación para el Desarrollo, A.C., 1990.

Katz, Isaac. "Un Análisis Económico de la Constitución.” Gaceta de Economía ITAM, Spring 1998, pp. 161-88.

Keeley, Michael C. "Deposit Insurance, Risk, and Market Power in Banking." American Economic Review, December 1990, 80(5), pp. 1183-1200.

La Porta, Rafael; López de Silanes, Florencio and Zamarripa, Guillermo. "Related Lending." Quarterly Journal of Economics, February 2003, 188(1), pp. 231-68.

Mackey, Michael W. "Informe de Michael W. Mackey en la Evaluación Integral de las Operaciones y Funciones del Fondo Bancario de Protección al Ahorro, FOBAPROA, y la Calidad de Supervisión de los Programas del FOBAPROA de 1995 a 1998." Gaceta Parlametaria, Año II, Número 352, September 13, 1999, Cámara de Diputados, H. Congreso de la Unión, México.

Martin, Antoine. "Liquidity Provision vs. Deposit Insurance: Preventing Bank Panics Without Moral Hazard.” Economic Theory, 2006, 28(1), pp. 197-211.
McQuerry, Elizabeth. "The Banking Sector Rescue in Mexico.” Federal Reserve Bank of Atlanta Economic Review, Third Quarter 1999, pp. 14-29.

McQuerry, Elizabeth and Espinosa, Marco. "Reviewing Mexico's New Bank Accounting Standards." Federal Reserve Bank of Atlanta Economics Update, January-March 1998.

Murillo, José Antonio. "La Banca en México: Privatización, Crisis, y Reordenamiento.” Unpublished manuscript, Banco de México, 2002.

Negrin, José Luis. "Mecanismos para Compartir Información Crediticia. Evidencia Internacional y la Experiencia Mexicana.” El Trimestre Económico, July-September 2001, 68(3), pp. 405-65.

Pickering, Natalie. "The SOFOLES: Niche Lending or New Lenders in the Mexican Mortgage Market?" Unpublished manuscript, Harvard University, 2000.

Schulz, Heiner. "Foreign Banks in Mexico: New Conquistadors or Agents of Change?" Unpublished manuscript, University of Pennsylvania, 2004.

Skelton, Edward C. "Laying the Foundation for a Mortgage Industry in Mexico.” Federal Reserve Bank of Dallas Economic Letter, October 2006, 1(10), pp. 14-18.

Trigueros, Ignacio. "El Sistema Financiero Mexicano." In Luis Rubio and Arturo Fernández, eds., México a la hora del cambio. México: Cal y Arena and Centro de Investigación para el Desarrollo, A.C., 1995.

Unal, Haluk and Navarro, Miguel. "The Technical Process of Bank Privatization in Mexico." Journal of Financial Services Research, September 1999, 16(1), pp. 61-83. 